\title{
Hydrogeology of the Archean Crystalline Rock Massif in the Southern Part of the Yenisseyskiy Ridge (Siberian Craton)
}

\author{
Andrey Ozers kiy \\ Krasnoyarskgeologia Joint Stock Company, Carl Marx Street, 62, Krasnoyarsk, Russia
}

Copyright $(2017$ by authors, all rights reserved. Authors agree that this article remains permanently open access under the terms of the Creative Commons Attribution License 4.0 International License

\begin{abstract}
The manuscript deals with the hydrogeological condition of Archean rock massif investigated for underground building of radioactive wastes isolation. Exploration methods included well boring up to depth of $700 \mathrm{~m}$, geophysical logging, hydrogeological pumping tests; water and rock sampling. Pumping tests carried out with systematically scaled intervals of 50 meters isolated by packers. Water samples were tested with chemical methods for main ions, ICP MS for trace elements and for radioactivity. Rock samples were tested in porosity, permeability, chemical composition, physical properties. Rock massif is represented by lower Archean gneisses pierced by dykes of dolerite. All rocks have very low reservoir properties due to an intense metamorphism. Laboratory tests have indicated that an average open porosity is equal to $0.33 \%$. Almost $70 \%$ of obtained values of hydraulic conductivity belong to the range of $0.0001 \mathrm{~m} \cdot$ day $^{-1}-0.001 \mathrm{~m} \cdot$ day $^{-1}$, while average hydraulic conductivity is equal to $0.004 \mathrm{~m} \cdot \mathrm{day}^{-1}$. There were found four vertical zones depending on the bases of drainage and differing in rock permeability and filtration conditions. The TDS of groundwater varies from 140 to $641 \mathrm{mg} \cdot \mathrm{L}^{-1}$, the type of water is $\mathrm{HCO}_{3}-\mathrm{Na}-\mathrm{Ca}$, water has alkaline and reductive media.
\end{abstract}

Keywords Gneiss, Archean, Repository, Impermeable Rock, Hydraulic Conductivity

\section{Introduction}

Hydrogeological conditions were investigated along with geological exploration of the rock massif for underground isolation of radioactive wastes. Perspective site of rock massif is situated in the south western part of the Siberian Craton that was named as Yenisseyskiy Ridge (Figure 1).

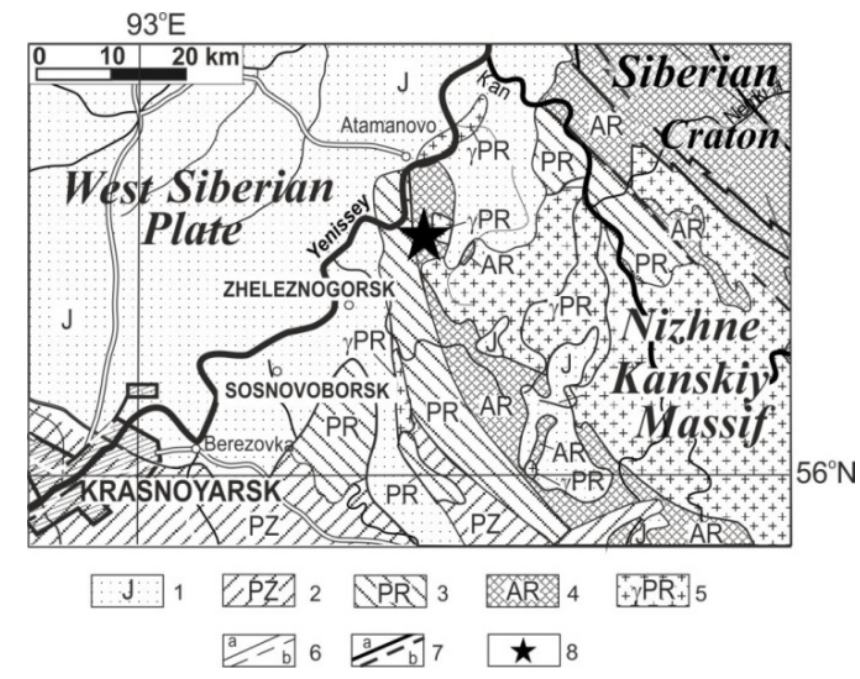

Legend. Hydrogeological units: 1 -Jurassic; 2 - Palaeozoic; 3 Proterozoic; 4 -Archean; 5 -Fissured aquifers in the intrusive rocks. $6-$ Borders of hydrogeological units, reliable (a) possible (б); 7 - tectonic faults, reliable (a) possible (б); 8 - studied massif.

Figure 1. Hydrogeological Survey Map

This structure during the last quarter of century magnetized the attention of Russian nuclear experts to create the repository of solid radioactive wastes. At first the underground isolation in Proterozoic granites of the Nizhne-Kanskiy massif was considered to be more reasonable in science [1].

However, it was later found that granites had some scarcities according to domestic and international safety rules. At the same time a new more advantageous massif mainly formed by Archean gneisses with dykes of gabbros or dolerites was revealed. This site is situated in $60 \mathrm{~km}$ north eastwards from Krasnoyarsk and 4-5 km away from the Yenissey river.

Hydrogeological investigations play the special role within geological exploration of repository sites.

Ground water plays two negative roles in relation to underground facility. At first groundwater creates inflow in 
underground facility and therefore it demands the drainage. We suppose that the second negative role is connected with a migration of radionuclides in the water media.

Both these roles postulate the highest demands to reliability and correctness of the studying of hydrogeological conditions. Obtained hydrogeological information must include a knowledge regarding the permeability of the geological formations, groundwater flow velocity and its direction, groundwater chemical composition, structural and geochemistry barriers and other data.

\section{Methods of Investigation}

Exploration methods were based on domestic and international safety demands [2, 4]. Exploration methods included well boring up to depth of $700 \mathrm{~m}$, geophysical logging, hydrogeological pumping tests, and also water and rock sampling. In total 8 single wells and 2 well clusters consisting of three wells each were drilled.

The field testing in single wells was performed with systematically scaled intervals of 50 meters isolated by packers. Discharge of water and water level (head) were controlled during pumping (bailing) and recovery period. Transmissivity and hydraulic conductivity were calculated from recovery data with Theis method. Well clusters were tested with standard method of pumping. Groundwater sampling was conducted during pumping before recovery period. The 102 water samples that were taken were tested with chemical methods for main ions, inductively coupled plasma mass spectrometry (ICP MS) and radiometry for trace elements and radioactivity. Rock samples were tested in porosity, gas permeability, and also in chemical and isotopic composition, physical, mechanical and deformation properties. Rock petrographic composition was investigated in thin sections.

\section{Results and Discussion}

The obtained results results show that the rock massif is represented by lower Archean gneisses pierced by dykes of dolerite or gabbro-diabase. The massif was formed under conditions of granulite facies of regional metamorphism.

Gneisses form about 4/5 of the geological section of the rock massif. The dominant minerals of gneisses are quartz (3-50\%), plagioclase $(25-70 \%)$, potassium feldspar (5$20 \%$ ), biotite (5-30\%), muscovite (15-20\%), and sillimanite (3-10\%). The mineral composition of dykes is formed by plagioclase $(20-60 \%)$, actinolite $(5-60 \%)$ or hornblende (up to $40-45 \%$ ), diopside (3-35\%) and quartz (3-10\%).

On the surface massif is covered with quaternary mantle rocks: loam, sandy loam and sand with gravel and debris. This cover is slightly permeable and therefore it does not play a significant role in the water supply of bedrock.

High level of metamorphism causes a great strength of crystalline bedrocks where the decrease of strength is only determined by the presence of fractures. Unconfined compressive strength varies in gneisses from 78.6 to 104 $\mathrm{MPa}$ and in dykes from 117 to $182 \mathrm{MPa}$, depending on the degree of fracturing.

All crystalline rocks have very low reservoir properties due to an intense metamorphism. Laboratory tests have indicated that an open porosity is $0.33 \%$ on average and, in any case, porosity does not exceed $1 \%$ (Table 1 ). But, at the same time, the average open porosity of gneisses is almost 1.5 times higher than porosity of dykes. Such small value of open porosity plays a significant role in aquifers volume since the storativity is very small too, changing from 0.25 to $1.6 \%$.

Gas permeability of rocks in the samples is also very small. Gneisses have a higher open porosity than dykes. An important difference between gneisses and dykes is the fact that gneisses have the anisotropic permeability, whereas filtration media of dykes is isotropic (Table 1).

All types of rocks tested in vitro in laboratories are impermeable according to Russian standards [5]. Moreover, the hydraulic conductivity of unfissured rocks corresponds to usual waterproof concrete.

The gneisses play a leading role in groundwater filtration, whereas dyke rocks form "more impermeable" sheets in the whole impermeable massif. The anisotropy of gneisses conductivity along with their structure, creates a favorable direction for the horizontal groundwater movement above vertical movements.

Table 1. Average values of open porosity and permeability in core samples of Archean rocks

\begin{tabular}{|c|c|c|c|}
\hline \multirow{2}{*}{$\begin{array}{c}\text { Rocks, } \\
\text { number of tests }\end{array}$} & \multirow{2}{*}{$\begin{array}{c}\text { Permeability, } \mathrm{m}^{2} / \\
\text { Open porosity, } \%\end{array}$} & Parallel to schistosity & Perpendicular to schistosity \\
\cline { 3 - 4 } & & $2 \cdot 10^{-17} / 1.2 \cdot 10^{-5}$ & $1.4 \cdot 10^{-17} / 8.3 \cdot 10^{-6}$ \\
\hline Gneisses, $\mathrm{N}=24$ & 0,35 & $8.9 \cdot 10^{-18} / 5.4 \cdot 10^{-6}$ & $8.9 \cdot 10^{-18} / 5.4 \cdot 10^{-6}$ \\
\hline Dykes, $\mathrm{N}=8$ & 0,25 & \\
\hline
\end{tabular}

* Hydraulic conductivity was calculated at average measured temperature of groundwater $6.5^{\circ} \mathrm{C}$ 
Results of pumping tests in situ showed that within the whole studied rock bulk from the surface up to a depth of $700 \mathrm{~m}$ impermeable rocks prevail. They have hydraulic conductivity below $0.005 \mathrm{~m} \cdot \mathrm{day}^{-1}$ that is upper limit of impermeable rocks according to Russian standards [5] (Figure 2). Almost $70 \%$ of all values of hydraulic conductivity belong to the range of $0.0001 \mathrm{~m} \cdot \mathrm{day}^{-1}$ $0.001 \mathrm{~m} \cdot$ day $^{-1}$ (Figure 2).
The vertical distribution of rock permeability obeys vertical zoning, depending on hypsometric position of base levels of drainage as well as in other crystalline massifs (Table 2). Single extremely high and "hurricane" values of hydraulic conductivity were found only above the regional base drainage level-the level of the Yenissey river (Figure 3).

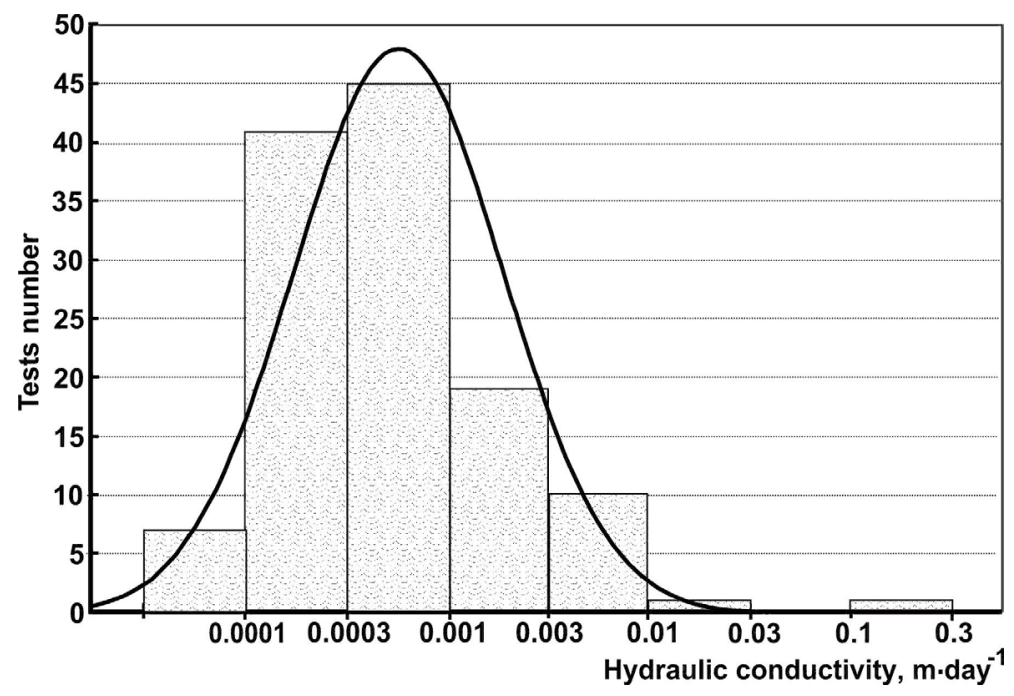

Figure 2. Histogram of hydraulic conductivity

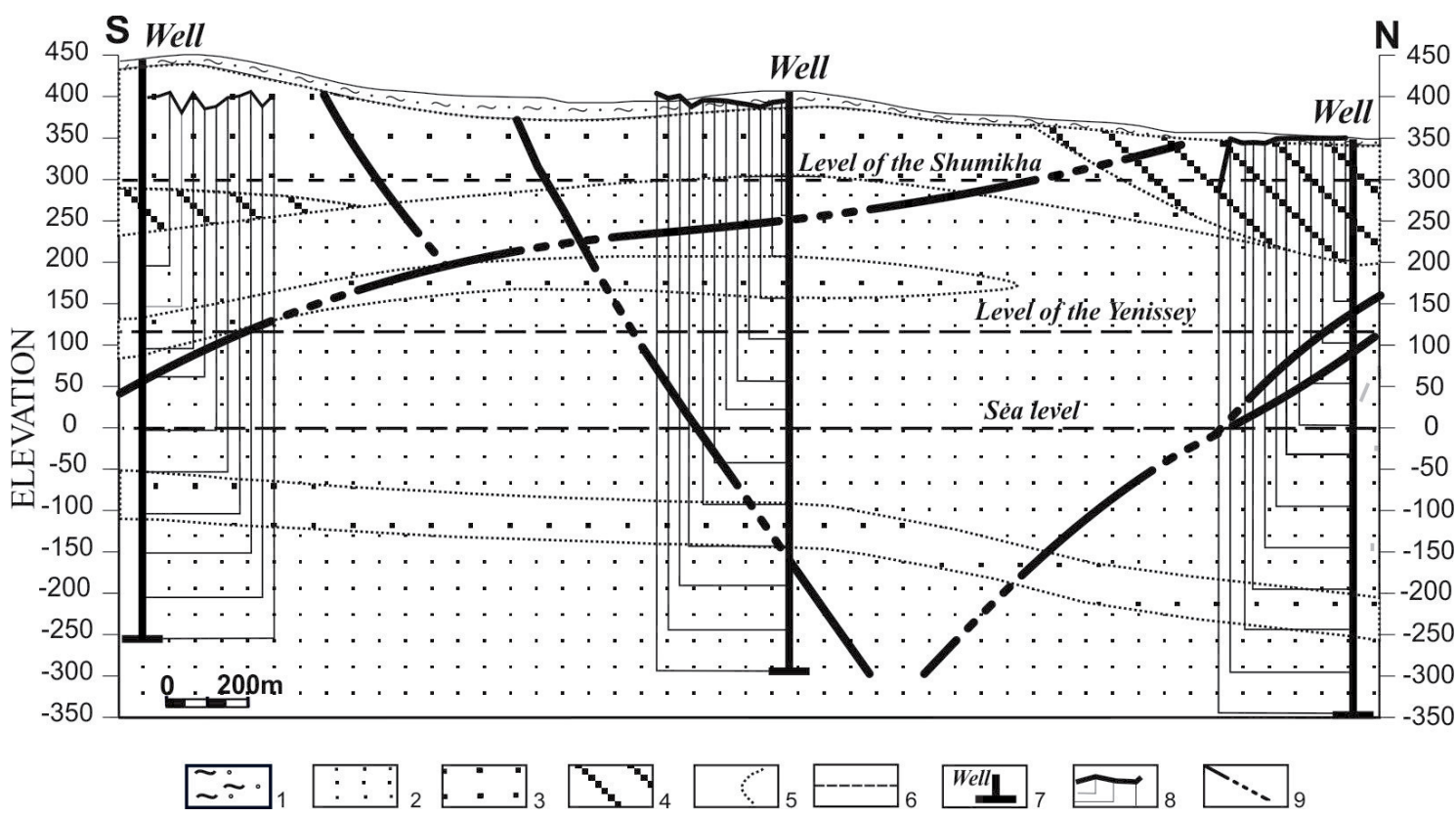

Legend. 1 - quaternary sediments (loam, sandy loam, clay), 2 - impermeable (KF $<0.001 \mathrm{~m} \cdot$ day $\left.^{-1}\right) ; 3$ - impermeable $\left(0.001 \mathrm{~m} \cdot \mathrm{day}^{-1}<\mathrm{KF}<0.005\right.$ $\mathrm{m} \cdot$ day $\left.^{-1}\right) ; 4$ - slightly permeable $\left(0.005 \mathrm{~m} \cdot\right.$ day $^{-1}<\mathrm{KF}<0.3 \mathrm{~m} \cdot$ day $\left.^{-1}\right) .5$ - borders of permeability units. 6 - base levels of draining river systems. $7-$ bored wells. 8 - heads in tested intervals and water level surface. 9-tectonic faults.

Figure 3. N-S Cross-Section across Studied Massif 


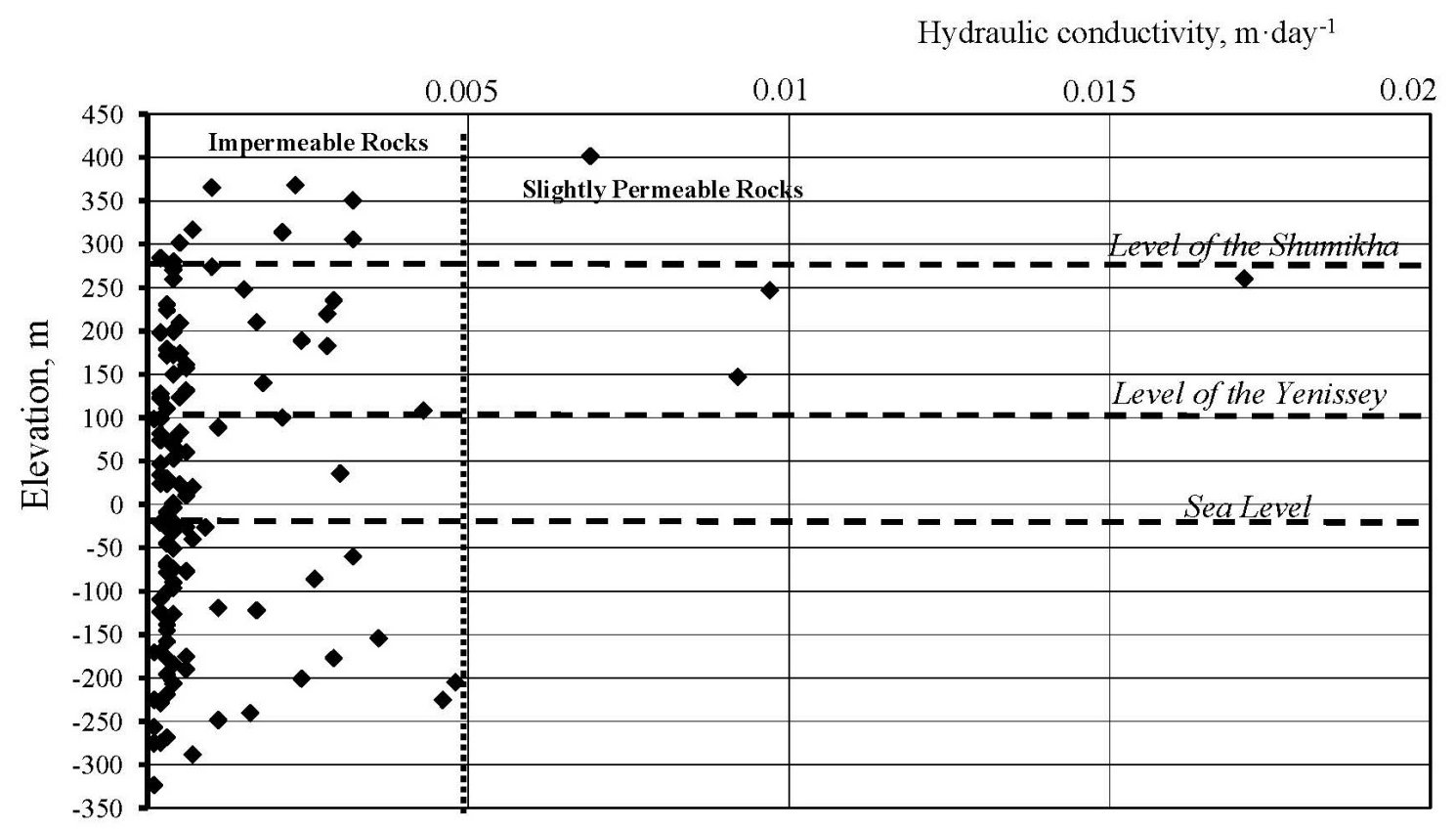

Figure 4. Distribution of hydraulic conductivity with depth

With a depth it appears irregularly fluctuating "background" of hydraulic conductivity, their values do not exceed $0.005 \mathrm{~m}^{\cdot \text { day }^{-1}}$ (Fig. 4).

The altitude of base levels determines vertical zoning of the massif permeability. We have distinguished four zones depending on the bases of drainage and differing in rock permeability and filtration conditions (Table 2).

The upper zone is located above the local drainage basis (above $300 \mathrm{~m}$ above sea level). This zone is characterized by the highest values of the hydraulic conductivity, as well as the presence of slightly aquifer rocks (hydraulic conductivity is higher than 0.005 $\left.\mathrm{m} \cdot \mathrm{day}^{-1}\right)$. Hydraulic diffusivity, estimated by a single pumping test, is equal to $1620 \mathrm{~m}^{2} \cdot \mathrm{day}^{-1}$.

Every table must have a unique title placed at the top. Titles should be clear and concise, and they should not be Middle zone, located between the local and regional base levels $(300-120 \mathrm{~m})$, is characterized by a significant reduction of the hydraulic conductivity, although slightly aquifer rocks occur in this zone. Hydraulic diffusivity here is higher than in the upper region and is equal to $5 \times 10^{4}$ $\mathrm{m}^{2} \cdot$ day $^{-1}$.

Two zones, located deeper than regional base levels, are characterized by stabilization of hydraulic conductivity that have approximately equal values. All rocks in these deepest zones are impermeable (Table 2). That is why this deep zone is planned to build a repository. Hydraulic conductivity of the studied gneisses is lower than the one of cognate Archean gneisses in the repositories Forsmark (Sweden) and Olkiluoto (Finland) [3]. On the other hand, the permeability of granite batholith du Bonnet, where was built the Canadian Underground Research Laboratory, is several times below [6]. Perhaps inland hydrogeological conditions of crystalline shields are more favorable for the construction of the radioactive wastes repositories than coastal ones.

Table 2. Vertical zoning of the massif of impermeable archean rocks

\begin{tabular}{|l|c|c|c|}
\hline \multirow{2}{*}{ Zones of permeability } & \multirow{2}{*}{$\begin{array}{c}\text { Elevation, } \mathrm{m} \\
\text { above sea } \\
\text { level }\end{array}$} & \multicolumn{2}{|c|}{$\begin{array}{c}\text { Hydraulic } \\
\text { conductivity, } \text { may }^{-1}\end{array}$} \\
\cline { 3 - 4 } & $>300$ & Average & Median \\
\hline $\begin{array}{l}\text { Upper, above local base } \\
\text { level }\end{array}$ & 0.0025 & 0.0023 \\
\hline $\begin{array}{l}\text { Middle, between local and } \\
\text { regional base levels }\end{array}$ & $300-120$ & 0.0018 & 0.0005 \\
\hline $\begin{array}{l}\text { Lower, between regional } \\
\text { and global base levels }\end{array}$ & $120-0$ & 0.0007 & 0.0004 \\
\hline $\begin{array}{l}\text { Deep, deeper global base } \\
\text { level }\end{array}$ & $0--350$ & 0.0008 & 0.0004 \\
\hline
\end{tabular}

The comparison of hydraulic conductivity measured in the laboratory samples (porous collector) and in the massif (porous and fissured reservoirs) shows that the share of porous collector in underground flow is approximately equal to $1 \%$ and does not exceed $3 \%$.

Measuring of groundwater levels derived for every tested interval have shown that the hydrostatic head extends to all studied depth of $700 \mathrm{~m}$. Therefore, the groundwater flow patterns are mainly controlled by the Earth's surface. Pressure drop occurs with average gradient of 0.05 in two directions: to the north-east, towards the local drains, and to the west in the direction of regional drains, the Yenissey river.

The total dissolved solids (TDS) of groundwater varies from 140 to $641 \mathrm{mg} \cdot \mathrm{L}^{-1}$ The average value is equal to 367 $\mathrm{mg} \cdot \mathrm{L}^{-1}$. The type of the water in the massif is alkaline with a reducing media. The average value of reduction potential (Eh) is equal to $-44.8 \mathrm{mV}$, and the average value of $\mathrm{pH}$ is equal to 8.0. Amongst dissolved gases the nitrogen $77.6 \%$ vol., carbon dioxide $16 \%$, and oxygen $5.9 \%$ prevail. 
Carbon dioxide has probably relict metamorphic origin.

Vertical zoning of permeability is confirmed in vertical zoning of the groundwater chemical composition, but hydro-geochemical zoning is less contrastive (Table 3). The representative chemical type of groundwater is bicarbonate sodium-calcium. The chemical composition of the three upper zones is similar, but composition of the deep zone essentially differs. Deep zone has the lowest TDS and concentrations of main ions that reflect a stability of the deepest rocks to dissolution. The hazardous components that can threat to fish resources are $\mathrm{Fe}, \mathrm{Cu}, \mathrm{Mo}$, $\mathrm{Cr}, \mathrm{Zn}$.

Natural radioactivity of groundwater in most samples is below the limits of analytical sensitivity. Alpha-activity was found in $42 \%$ of samples that indicates the presence of dissolved radon, released into groundwater after natural decay of radium-226. Beta-activity was detected in $21 \%$ of samples with varying activities $0,13-0,64 \mathrm{~Bq} \cdot \mathrm{L}^{-1}$, in any case it does not exceed the threshold level for drinking water $\left(1 \mathrm{~Bq} \cdot \mathrm{L}^{-1}\right)$.

Table 3. Zoning of groundwater chemical composition, $\mathrm{mg} \cdot \mathrm{L}^{-1}$

\begin{tabular}{|c|c|c|c|c|}
\hline \multirow{2}{*}{ Components } & \multicolumn{4}{|c|}{ Zones of permeability } \\
\cline { 2 - 5 } & Upper & Middle & Lower & Deep \\
\hline $\mathrm{HCO}_{3}^{-}$ & 220 & 232 & 247 & 215 \\
\hline $\mathrm{Cl}^{-}$ & 4 & 5 & 6 & 5 \\
\hline $\mathrm{SO}_{4}^{2-}$ & 19 & 26 & 21 & 16 \\
\hline $\mathrm{Ca}^{2+}$ & 56 & 42 & 54 & 44 \\
\hline $\mathrm{Mg}^{2+}$ & 11 & 10 & 12 & 9 \\
\hline $\mathrm{Na}^{+}$ & 19 & 33 & 26 & 25 \\
\hline $\mathrm{K}^{+}$ & 2,6 & 2,7 & 2,6 & 2,7 \\
\hline $\mathrm{Fe}$ total & 1,4 & 4,4 & 3,1 & 4,1 \\
\hline $\mathrm{TDS}$ & 369 & 376 & 394 & 343 \\
\hline
\end{tabular}

\section{Conclusions}

1. Crystalline rocks up to depth of $700 \mathrm{~m}$ contain small quantity of free groundwater that is chiefly contained in fissured collector. Only about $1 \%$ of groundwater places in porous media.

2. The permeability of metamorphic rocks is very small, the median value of hydraulic conductivity is equal to $0.0004 \mathrm{~m} \cdot \mathrm{day}^{-1}$.

3. In almost impermeable rocks the head (pressure) is transmitted to the whole studied thickness, therefore, groundwater flow patterns are mainly controlled by the Earth's surface at any depth.

4. In the almost impermeable media a groundwater movement is not entirely performed by Darcy's law.
Some part of water flows involving forces of the viscosity and capillarity.

5. Groundwater in crystalline rocks is characterized by a vertical zoning that depends on base levels of draining river systems.

6. Groundwater in Archean gneisses belongs to the $\mathrm{Na}-\mathrm{Ca}-\mathrm{HCO}_{3}$ type. The TDS never exceeds 650 $\mathrm{mg} \cdot \mathrm{L}^{-1}$. Ground waters are mainly slightly alkaline (average $\mathrm{pH}=8.0$ ), their average redox potential is equal to $-29 \mathrm{mV}$;

7. Hydrogeological conditions of studied Archean crystalline massif correspond to domestic and international safety requirements for radioactive waste repository. The massif is mainly represented by impermeable rocks with a very small permeability.

8. Tectonic fractures are mostly healed by dykes of intrusive rocks and veins of secondary minerals. Therefore, fractures do not appear to increase hydraulic conductivity and they can't serve as channels of hydraulic connection between depth interval of repository and the Earth's surface.

\section{REFERENCES}

[1] Anderson Ye. B., Lyubtseva Ye. F., Savonenkov V. G., Shabalev S. I., and Alekseev N. L. Creation of an Underground Storage Facility for Spent Nuclear Fuel near the City of Zheleznogorsk (Eastern Siberia). An International Spent Nuclear Fuel Storage Facility. Exploring a Russian Site as a Prototype: Proceedings of an International Workshop. The National Academies Press, Washington, DC, USA, 166:176, 2005

[2] Burial of radioactive waste disposal. Principles, criteria and essential safety requirements (NP-055-14). Approved by the Federal Service for Ecological, Technological and Nuclear Supervision of 22.08.2014 № 379. 26 p., 2014 (in Russian),

[3] Geier J., Bath A., and Stephansson O. Comparison of site descriptive models for Olkiluoto, Finland and Forsmark, Sweden. STUK-TR 14, Helsinki, 64 pp., 2012

[4] Geological disposal facilities for radioactive waste : specific safety guide. - Vienna : International Atomic Energy Agency, 104 p., 2011.

[5] GOST 25100-2011. Soils. Classification. Moscow: Standartinform, 2013. - 38 p. (in Russian)

[6] Stevenson D.R., Kozak E.T., Davison C.C., Gascoyne M. and Broadfoot R.A. Hydrogeologic characteristics of domains of sparsely fractured rock in the granitic Lac du Bonnet batholith, Southeastern Manitoba, Canada. Atomic Energy of Canada Limited. Whiteshell Laboratories, Pinawa, Manitoba, Canada, 27 p.,1996. 